УДК $342.922 ; 351.86$

DOI https://doi.org/10.32837/apdp.v0i86.2426

В. Я. Настюк, І. М. Коропатнік, В. В. Карелін

\title{
РОЗВИТОК ТА СТАНОВЛЕННЯ МЕХАНІЗМУ РЕАЛІЗАЦІЇ АДМІНІСТРАТИВНО-ПРАВОВОГО РЕЖИМУ ЦИВІЛЬНО-ВІЙСЬКОВОГО СПІВРОБІТНИЦТВА В УКРАЇНІ
}

Вступ. Проблема установлення й реалізації адміністративно-правових режимів у межах будь-якої держави та її органів останнім часом усе частіше стає предметом наукових розвідок. В.В. Бєлєвцева у своєму монографічному дослідженні під назвою «Організаційно-правове забезпечення адміністративно-правових режимів у сфері державної безпеки України», зокрема, зазначає, що такі режими є невід’ємним атрибутом будь-якого розвинутого суспільства та, окрім цього, є однією з базових умов його функціонування й розвитку, бо саме адміністративно-правові режими формують і забезпечують реалізацію державою наявних у неї функцій захисту. Водночас розглядувані режими базуються на тих же принципах, що й державне управління в адміністративно-політичній діяльності, використовують для свого функціонування такі самі методи, існують у тотожних формах. Водночас адміністративно-правові режими характеризуються й власними відмітними рисами, зумовленими функціями та завданнями, що покладаються на відповідний державний орган, залучений до діяльності з гарантування державної безпеки у відповідному секторі [1, с. 5].

Реформування Збройних сил України й удосконалення правового регулювання діяльності щодо організації цивільно-військового співробітництва в наш час свідчать про наявність позитивних тенденцій у забезпеченні належних умов для взаємодії військовослужбовців та цивільного населення.

Оскільки адміністративно-правові режими формують і забезпечують реалізацію державою наявних в неї функцій захисту, то варто дослідити таке правове явище, як адміністративно-правовий режим цивільно-військового співробітництва.

Стан дослідження. Питання адміністративно-правових режимів у тому чи іншому аспекті досліджували як вітчизняні, так і закордонні автори, а саме: В.Б. Авер'янов, О.М. Бандурка, В.В. Бєлєвцева, Ю.П. Битяк, О.Г. Братель, А.С. Васильєв, І.П. Голосніченко, В.В. Зуй, С.В. Ківалов, Т.О. Коломоєць, В.М. Комарницький, А.Т. Комзюк, С.О. Кузніченко, С.К. Могил, Т.П. Мінка, В.Я. Настюк, С.В. Пєтков, В.М. Плішкін, М.М. Тищенко й ін.

А до питання цивільно-військового співробітництва звертались також низка науковців юристів та військовослужбовців, зокрема: Б.В Бернадський, С.І. Денисенко, Р.О. Додонов, В.В. Коваленко, І.М. Коропатнік, В.О. Кушнір, О.О. Оліфіров, С.В. Пєтков, І.П. Рущенко, С.М. Салкуцан, О.Ф. Сальнікова, В.М. Тарасов, В.М. Телелим, І.М. Шопіна й ін.

Постановка завдання. Метою статті є дослідження розвитку та становлення механізму реалізації адміністративно-правового режиму цивільно-військового співробітництва в Україні. 
Результати дослідження. Одним з основних інструментів розуміння будь-якого правового явища, на нашу думку, є дослідження його розвитку та становлення. Адже історичний аналіз наукових джерел формування взаємодії війська із цивільним населенням $є$ основою подальшого розвитку правової моделі адміністративно-правового режиму цивільно-військового співробітництва. Дослідження процесу режимної діяльності цивільно-військового співробітництва доцільно почати з періоду існування двох незалежних українських держав Української Народної Республіки (далі - УНР) та Західноукраїнської Народної Республіки (далі ЗУНР). Це пояснюється, зокрема, тим, що саме від того часу закладено своєрідну матрицю розвитку суспільних відносин у досліджуваній сфері. До того ж поштовх у розвитку «взаємодії між військовослужбовцями та цивільним населенням» відбувся приблизно в цей період [2].

На першому етапі, на початку XX ст., зокрема за часів існування незалежних українських держав УНР та ЗУНР, громадянське суспільство в Україні і правове регулювання державної політики у сфері взаємодії між ним і воєнною організацією перебували на стадії зародження. Нормативно-правові акти вирізнялись відсутністю системності та регулюванням окремих аспектів у цій сфері [2].

Другий етап розвитку правового регулювання державної політики у сфері взаємодії громадянського суспільства і воєнної організації проходив у часи перебування України у складі Союзу Радянських Соціалістичних Республік (далі-СРСР). У цей період формуються передумови створення громадянського суспільства в нашій державі. Цей етап завершився кризою тоталітарного режиму на території СРСР і набуттям нашою державою незалежності.

Правове регулювання державної політики у сфері взаємодії між воєнною організацією держави і суспільством за часів входження українських земель до складу СРСР потребує розгляду особливостей функціонування легалізованих громадських об'єднань. Зокрема, у 1927 р. було створено Товариство сприяння обороні, авіаційному і хімічному будівництву (далі - OCOABIAXIM) - радянську суспільно-політичну оборонну організацію. У 1948 р. на його базі створено три самостійні товариства - ДОСАРМ, ДОСАВ і ДОСФЛОТ, які в 1951 р. об’єдналися у структурі Добровільного товариства сприяння армії, авіації і флоту (далі - ДТСААФ) добровільного самоврядного суспільно-державного об'єднання, метою якого декларувалося сприяння зміцненню обороноздатності країни і національної безпеки. Основними його завданнями визначалися виховання членів суспільства в дусі постійної готовності до захисту інтересів соціалістичної Батьківщини і любові до радянських Збройних сил, пропаганда серед населення військових знань, традицій радянського народу і його Збройних сил, підготовка молоді до військової служби відповідно до вимог Закону СРСР про загальний військовий обов'язок, сприяння заходам цивільної оборони, участь у підготовці для народного господарства кадрів масових технічних професій, що мають військове прикладне значення, трактористів, радистів, мотористів, електриків, мотоциклістів та ін., здійснення керівництва розвитком у країні військово-технічних видів спорту тощо [2].

Аналіз зазначених вище завдань свідчить про жорстке підпорядкування громадянської активності в даній сфері інтересам і потребам державного апарату. 
По суті, особистий час молодь присвячувала підготовці до подальшої служби у Збройних силах, що дозволяло значно заощадити кошти, що виділяються на утримання майбутніх військовослужбовців у період їх навчання. Крім того, до свідомості молодих людей активно впроваджувалася думка про пріоритетність військових потреб держави над будь-якими іншими проявами особистої активності. На виході подібні ДТСААФ декларативні громадські об’єднання, створювані за вказівкою панівної на той час партії, дозволяли отримати ідеологічно оброблених, фізично підготовлених майбутніх військовослужбовців, що володіють певними навичками управління військовою технікою, і все це ще й завдяки відрахуванням з їхніх невеликих зарплат і стипендій у вигляді членських внесків [2].

Проте за часів так званої «перебудови» 1985-1991 pр. в УРСР почали з'являтись громадські організації політичної спрямованості.

Як зауважує А.Ф Колодій, перехід до громадянського суспільства і правової держави розпочався з делегітимізації влади в колишньому СРСР. Оскільки одним із головних засобів легітимізації влади партійної верхівки була ідеологія, то криза легітимності проявилася передусім як зростання усвідомлення невідповідності ідеологічних гасел і практичної діяльності панівної верхівки, подвійності стандартів, які вона застосовувала до себе та свого оточення, з одного боку, і до решти громадян, з іншого. Перебудова, декларованими цілями якої були підвищення рівня демократії й економічне зростання, була сприйнята населенням із надзвичайним ентузіазмом. Саме гласність мала вирішальне значення для відновлення громадянського життя наприкінці 80-х - на початку $90-\mathrm{x}$ pp. [3, с. 14].

Серед таких організацій варто назвати об'єднання солдатських матерів, які наприкінці 80-x - на початку 90 -х рр. минулого століття виступили одним з активних учасників взаємодії між громадянським суспільством і воєнною організацією.

Отже, у часи, коли українські землі перебували у складі СРСР, проходив другий етап розвитку правового регулювання державної політики у сфері взаємодії громадянського суспільства і Збройних сил України. У цей період щодо легалізованих громадських об'єднань із боку держави здійснювався майже цілковитий контроль. Ці громадські організації започатковувались та формувались з ініціативи органів державної влади для виконання функцій держави. Утворюючи громадські об'єднання для взаємодії з армією. Комуністична партія Радянського Союзу ставила за мету не лише фізичну та військову підготовку майбутніх військовослужбовців, а насамперед вплив на їхню свідомість. Проте, незважаючи на штучність утворення та декларативність, по-перше, їхня діяльність сприяла формуванню громадянського суспільства в Україні, по-друге, співробітництво між такими організаціями та радянською армією відіграло свою позитивну роль під час Другої світової війни [2].

Третій етап взаємодії громадянського суспільства і Збройних сил України та правового регулювання державної політики в цій сфері розпочався зі здобуття незалежності Україною та створення власних Збройних сил. Він характеризується як становленням самого громадянського суспільства в нашій державі, так і синергією з воєнною організацією.

Перші кроки до запровадження взаємодії цивільного населення і Збройних сил України були зроблені ще на початку XXI ст., під час виконання миротворчих 
завдань в Республіці Ірак (2003-2005 рр.). Український миротворчий контингент (далі - УМК) у Республіці Ірак виконував миротворчі завдання у складних умовах глибокої економічної і соціальної кризи, хаосу, проявів тероризму і зростання організованої злочинності, унаслідок порушення системи державного управління у країні. Водночас був накопичений унікальний досвід щодо виконання завдань організації взаємодії з місцевими органами влади та надання допомоги місцевому населенню у провінції Васіт із метою створення сприятливих умов для виконання завдань УМК та досягнення кінцевої мети операції. Зазначений досвід підтвердив важливість здійснення заходів ЦВС, які разом із заходами щодо створення та підготовки національних сил безпеки Іраку були визначальними у стабілізації ситуації та зменшенні загрози диверсійно-терористичної діяльності з боку збройних формувань проти УМК [4].

Навесні 2014 р. війська Російської Федерації (далі - РФ) здійснили вторгнення на територію України. Спочатку їхня влада провела в Автономній Республіці Крим незаконний референдум, за результатами якого окупувала півострів, але цього їй здалося замало, вона почала захоплення інших адміністративно-територіальних одиниць нашої держави, результатом чого були створені на окупованій РФ частині окремих районів Донецької та Луганської областей (далі - ОРДЛО) так звані квазідержавні утворення «Донецька народна республіка» (далі - ДНР) і «Луганська народна республіка» (далі - ЛНР).

Офіційною реакцією на окупацію Кримського півострова з позицій внутрішньодержавного права стало ухвалення Закону України «Про забезпечення прав і свобод громадян та правовий режим на тимчасово окупованій території України» від 15 квітня 2014 р. (далі - Закон № 1207-VII), ст. 3 якого визнала сухопутну територію Кримського півострова, внутрішні води України цих територій, внутрішні морські води і територіальне море України, виключну (морську) економічну зону вздовж узбережжя Кримського півострова та прилеглого до узбережжя континентального шельфу, повітряний простір над цими територіями тимчасово окупованими територіями [5, с. 3].

Ст. 5 вищезазначеного Закону проголосила, що Україна вживає всіх необхідних заходів щодо гарантування прав і свобод людини і громадянина, передбачених Конституцією та законами України, міжнародними договорами, усім громадянам України, які проживають на тимчасово окупованій території України [5, с. 3].

Із загостренням ситуації наша держава втратила контроль над ОРДЛО, а члени незаконних збройних формувань почали захоплювати будівлі органів державної влади та місцевого самоврядування, зокрема й військових частин, органів та установ виконання покарань, управлінь юстиції, міліції (із 2015 р. - національна поліція), Служби безпеки України, прокуратури, суду тощо. Тобто українські правоохоронні та контролюючі органи припинили функціонувати на непідконтрольних уряду територіях. Після чого нашою державою був уведений режим антитерористичної операції, який, у свою чергу, у 2018 р. переріс в операцію Об'єднаних сил.

Антитерористична операція (англ. Antiterrorist operation) (далі - ATO) - комплекс скоординованих спеціальних заходів, спрямованих на запобігання терористичній діяльності, їі припинення, звільнення заручників, гарантування 
безпеки населення, знешкодження терористів, мінімізацію наслідків терористичної діяльності [6].

Операція Об’єднаних сил (англ. Joint forces operation) (далі - OOC) - комплекс військових та спеціальних організаційно-правових заходів українських силових структур, спрямований на протидію діяльності незаконних російських та проросійських збройних формувань у війні на Сході України [7].

Збройний конфлікт на Сході України держава визначила як терористичну загрозу і загрозу територіальній цілісності України, розгорнула антитерористичну операцію. Згодом постановою Верховної Ради України від 17 березня 2015 р. № 254-VIII «Про визнання окремих районів, міст, селищ і сіл Донецької та Луганської областей тимчасово окупованими територіями» (далі - постанова № 254-VIII) визнано тимчасово окупованими територіями окремі райони, міста, селища і села Донецької та Луганської областей, у яких, відповідно до Закону України «Про особливий порядок місцевого самоврядування в окремих районах Донецької та Луганської областей», запроваджується особливий порядок місцевого самоврядування, до моменту виведення всіх незаконних збройних формувань, російських окупаційних військ, їхньої військової техніки, а також бойовиків і найманців із території України та відновлення повного контролю України за державним кордоном України [5, с. 3].

Відсутність дієвої системи популяризації й інформування про діяльність Збройних сил України й агресивна антиукраїнська пропаганда з боку РФ створили передумови для появи недовіри, а іноді і протидії з боку місцевого населення окремих районів Донецької та Луганської областей, що надало деякі тимчасові переваги незаконним збройним формуванням та підрозділам збройних сил РФ [8].

На початку 2014 р. постало питання створення Управління цивільно-військового співробітництва як окремого військового органу та початку розвитку системи відповідно до стандартів НАТО. Українська держава звернулась до своїх партнерів. Перше відгукнулося Об'єднане командування ОЗС НАТО Брюнсум. Воно надіслало фахівців із різних країн, однак підходи Альянсу виявилися таким, що не збігалися на той час із суспільно-політичною та воєнно-стратегічною обстановкою в Україні. НАТО не мало досвіду. як збройні сили повинні діяти зі своїм цивільним середовищем, своїми правоохоронними органами. Адже система ЦВС Альянсу будувалась із розрахунку дій у складі коаліційних або миротворчих контингентів [9].

Цивільно-військове співробітниитво в Україні офіційно було започатковано для координації взаємодії силових структур із місцевою владою, бізнесом та міжнародними організаціями для вирішення проблем цивільного населення в зоні збройного конфлікту на сході України, як пілотний проєкт 5 травня 2014 р., рішенням в. о. обов'язки міністра оборони України на базі Національного університету оборони України ім. Івана Черняховського, де було розпочато підготовку офіцерів, які повинні були займатися вищевказаною діяльністю на прифронтових територіях проведення антитерористичної операції в Донецькій та Луганській областях. Начальником Генерального штабу - Головнокомандувачем Збройних сил України видано наказ від 3 лютого 2015 р. № 34, яким уведено в дію Положення про Управління цивільно-військового співробітництва Збройних сил України. 
Натепер діяльність вищезазначеного Управління перебуває на стадії становлення та розвитку.

Питання здійснення організації цивільно-військового співробітництва в умовах проведення ООС в окремих районах Донецької та Луганської областей є актуальним, оскільки саме воно багато в чому визначає ефективність діяльності Збройних сил України, - мир та порядок у державі. Це, на нашу думку, зумовлює необхідність розгляду цього питання більш глибоко.

Цивільно-військове співробітництво - це систематична, планомірна діяльність Збройних сил України, інших військових формувань та правоохоронних органів, утворених відповідно до законів України (далі - Збройні сили України) з координації та взаємодії з органами виконавчої влади, органами місцевого самоврядування, громадськими об’єднаннями, організаціями та громадянами в районах дислокації військових частин та підрозділів Збройних сил України з метою формування позитивної громадської думки і забезпечення сприятливих умов для виконання Збройними силами України покладених на них завдань і функцій шляхом надання допомоги цивільному населенню у вирішенні проблемних питань життєдіяльності з використанням військових та невійськових сил та засобів [9].

Управління иивільно-військового співробітництва (далі - УЦВС) - орган Збройних сил України, що був створений у 2014 р. для координації взаємодії силових структур із місцевою владою, бізнесом та міжнародними організаціями для вирішення проблем цивільного населення в зоні збройного конфлікту на сході України [9].

Основні завдання структур ЦВС України такі: проведення заходів із формування позитивної громадської думки щодо діяльності Збройних сил України, зокрема під час участі у стабілізаційних (антитерористичних) операціях, уведення правового режиму надзвичайного чи воєнного стану, операцій із підтримання миру і безпеки та ліквідації наслідків надзвичайних ситуацій; оцінка розвитку політичної, соціально-економічної, екологічної, санітарноепідеміологічної ситуації, міжконфесійних та міжетнічних відносин із метою визначення дестабілізуючих факторів у районах дислокації військових частин та підрозділів Збройних сил України (українських миротворчих контингентів), прогнозування їхнього впливу на умови виконання завдань; аналіз місцевих політичних, культурних, історичних, етнічних особливостей, стану національного та місцевого управління, економічного розвитку, потреб місцевого населення, міграції (переміщення) населення, присутності і діяльності міжнародних урядових і неурядових організацій, а також релігійних та інших організацій; співпраця із цивільним населенням, місцевими органами влади, міжнародними урядовими і неурядовими організаціями, а також релігійними й іншими організаціями в зоні діяльності військових частин та підрозділів Збройних сил України з метою створення сприятливих умов для виконання завдань; взаємодія з місцевими органами влади щодо надання в установленому порядку військовим частинам та підрозділам Збройних сил України підтримки у формі робіт, послуг і матеріальних засобів; надання допомоги місцевим органам влади в зоні діяльності військових частин та підрозділів Збройних сил України з питань відновлення інфраструктури, забезпечення стабільності і безпеки, нормалізації 
життя цивільного населення; визначення можливостей місцевих органів влади, громадських, релігійних, міжнародних організацій щодо надання допомоги цивільному населенню в зоні діяльності військових частин та підрозділів Збройних сил України; координація зусиль місцевих органів влади, громадських і міжнародних організацій щодо збалансованого використання ресурсів для відновлення об'єктів цивільної інфраструктури та забезпечення допомоги цивільному населенню в зоні діяльності військових частин та підрозділів Збройних сил України; сприяння створенню робочих місць для місцевого населення у сфері відновлення цивільної інфраструктури, підготовці відповідних кваліфікованих кадрів у взаємодії з місцевими органами влади, міжнародними й іншими організаціями; координація надання гуманітарної допомоги цивільному населенню в зоні діяльності військових частин та підрозділів Збройних сил України; співпраця з місцевими лідерами, місцевим населенням у зоні діяльності військових частин та підрозділів Збройних сил України з метою формування позитивної громадської думки щодо діяльності Збройних сил України [10, с. 1-2].

Концепція цивільно-військового співробітництва не нова для багатьох провідних армій світу. Розглядаючи різноманітні національні підходи до підготовки та принципів застосування підрозділів ЦВС, можна багато чому навчитися, зокрема й на чужих помилках. Безумовно, аналіз та накопичення такого досвіду стане беззаперечним внеском у розвиток системи цивільно-військового співробітництва у Збройних силах України, виведе їх на рівень взаємосумісності під час проведення багатонаціональних операцій, навчань тощо [11, с. 28].

Висновки. Отже, після запровадження в Україні адміністративно-правового режиму цивільно-військового співробітництва на визволених територіях України підвищилася довіра місцевих жителів до діяльності Збройних сил України в районах дислокації військових частин та підрозділів угруповань військ. Надається допомога цивільному населенню визволених територій, а також організовано взаємодію з іншими військовими формуваннями та правоохоронними органами, місцевими органами влади, засобами масової інформації, різноманітними гуманітарними організаціями та приватним сектором у районах проведення ООС.

Аналіз нормативно-правових актів, наукової та навчальної літератури дає підстави для висновку, що процес реалізації адміністративно-правового режиму цивільно-військового співробітництва і дотепер неповно висвітлений вітчизняними та закордонними науковцями. Можна припустити, що основна причина такого явища полягає в тому, що виникнення, становлення й удосконалення системи співробітництва цивільного населення та військової організації, починаючи 3 періоду існування УНР та ЗУНР в історії України і закінчуючи сьогоденням, характеризується хронічною політичною нестабільністю та постійним реформуванням означеної сфери, особливо за сучасних умов. 


\section{Jimepamypa}

1. Бєлєвцева В. В. Організаційно-правове забезпечення адміністративно-правових режимів у сфері державної безпеки України : монографія. Харків : Право, 2013. 352 c.

2. Коропатнік I.М. Генеза правового регулювання взаємодії воєнної організації та громадянського суспільства. Форум права. 2016. № 3. C. 154-158. URL: http://nbuv.gov.ua/UJRN/FP_index.

3. Колодій А.Ф. Поняття і концепції демократичного врядування як напряму політичних та управлінських досліджень. Демократичне врядування в контексті глобальних викликів та кризових ситуацій : матеріали Міжнародної науково-практичної конференції, 3 квітня 2009 р. Львів : ЛРІДУ НАДУ при Президентові України, 2009. С. 10-25.

4. Удосконалення системи підготовки фахівців цивільно-військового співробітництва у Збройних силах України / В.В. Школяренко та ін. Збірник наукових праць Харківського університету Повітряних Сил. 2012. Вип. 1 (30). С. 46-51.

5. Перешкоди в реалізації прав і свобод осіб на окупованій території Кримського півострова та тимчасово непідконтрольних територіях Донецької та Луганської областей (реєстрація фактів народження і смерті) : аналітичний звіт ГО Центр правових та політичних досліджень «СІМ». ГС Українська Гельсінська спілка з прав людини. URL: https://helsinki.org.ua/wp-content/uploads/2018/02/Zvi1t.pdf.

6. Про боротьбу з тероризмом : Закон України від 20 березня 2003 р. № 638-IV. База даних «Законодавство України» / ВР України. URL: http://zakon0.rada.gov.ua/laws/show/638-15.

7. Операція Об'єднаних сил. Вікіпедія. URL: https: //uk.wikipedia.org/wiki/Операція_об\% 27єднаних_сил.

8. Пояснювальна записка до проєкту Закону України «Про внесення змін до законів України «Про Збройні Сили України» та «Про оборону України» (щодо здійснення Збройними Силами України цивільно-військового співробітництва)». URL: w1.c1.rada.gov.ua/pls/zweb2)webproc34.

9. Голуби миру у військовій формі. Ч. 1. URL: https://defence-ua.com/index.php/statti/8054holuby-myru-u-viyskoviy-formi-ch1.

10. Цивільно-військове співробітництво за стандартами НАТО : навчальний посібник. Київ : НУОУ ім. Івана Черняховського, 2015. 87 с.

\section{Анотація}

Настюк В. Я., Коропатнік І. М., Карелін В. В. Розвиток та становлення механізму реалізації адміністративно-правового режиму цивільно-військового співробітництва в Украйні. - Стаття.

У статті розглядається необхідність дослідження проблем розвитку та становлення механізму реалізації адміністративно-правового режиму цивільно-військового співробітництва в Україні. Зазначено, що питання адміністративно-правових режимів у тому чи іншому аспекті досліджували як вітчизняні, так і закордонні автори, а саме: В.Б. Авер'янов, О.М. Бандурка, Є.О. Бараш, В.В. Бєлєвцева, Ю.П. Битяк, О.Г. Братель, А.С. Васильєв, І.П. Голосніченко, В.В. Зуй, С.В. Ківалов, Т.О. Коломоєць, В.М. Комарницький, А.Т. Комзюк, С.О. Кузніченко, С.К. Могил, Т.П. Мінка, В.Я. Настюк, С.В. Пєтков, В.М. Плішкін, М.М. Тищенко й інші.

А до питання цивільно-військового співробітництва звертались також низка науковців юристів та військовослужбовців, зокрема: Б.В. Бернадський, С.І. Денисенко, Р.О. Додонов, В.В. Коваленко, I.М. Коропатнік, В.О. Кушнір, О.О. Оліфіров, С.В. Пєтков, І.П. Рущенко, С.М. Салкуцан, О.Ф. Сальнікова, В.М. Тарасов, В. М. Телелим, І.М. Шопіна й інші.

Визначено основні нормативно-правові акти, які регулюють діяльність Управління цивільно-військового співробітництва в Україні.

Визначено, що після запровадження в Україні адміністративно-правового режиму цивільно-військового співробітництва на визволених територіях України підвищилася довіра місцевих жителів до діяльності Збройних сил України у районах дислокації військових частин та підрозділів угруповань військ. Надається допомога цивільному населенню визволених територій, а також організовано взаємодію з іншими військовими формуваннями та правоохоронними органами, місцевими органами влади, засобами масової інформації, різноманітними гуманітарними організаціями та приватним сектором у районах проведення операції Об’єднаних сил.

Констатовано, що процес реалізації адміністративно-правового режиму цивільно-військового співробітництва і дотепер недостатньо висвітлений вітчизняними та закордонними науковцями. Можна припустити, що основна причина такого явища полягає в тому, що виникнення, становлення й удосконалення системи співробітництва цивільного населення та військової організації, починаючи з періоду існування Української Народної Республіки та Західноукраїнської Народної Республіки 
в історії України і закінчуючи сьогоденням, характеризується хронічною політичною нестабільністю та постійним реформуванням означеної сфери, особливо за сучасних умов.

Ключові слова: операція Об’єднаних сил, цивільно-військове співробітництво, правовий режим, Збройні сили України, окупація.

\section{Summary}

Nastyk V.J., Koropatnik I. M., Karelin V.V. Development and establishment of administrative-legal regime mechanism realization of the Civil-Military Cooperation in Ukraine. - Article.

The article considers the necessity to investigate an issue of development and establishment of the mechanism realization of the administrative-legal regime of the civil-military cooperation in Ukraine. It is noted that the issue of the administrative-legal regimes in one or another aspects has been investigated by the national as well as foreign authors, in particular: V.B. Averyanov, O.M. Bandurka, E.O. Barash, V.V. Belevtseva, Y.P. Bytyak, O.H. Bratel, A.S. Vasyliev, I.P. Holosnichenko, V.V. Zuy, S.V. Kivalov, T.O. Kolomoets, V.M. Komarnytskyi, A.T. Komzyuk, S.O. Kuznichenko, S.K. Mohyl, T.P. Minka, V.Y. Nastyuk, S.V. Petkov, V.M. Plishkin, M.M. Tishchenko et al.

A number of the scientists, lawyer and militaries have also addressed the issue of civil-military cooperation, in particular: B.V. Bernadsky, P.I. Denysenko, P.O. Dodonov, V.V. Kovalenko, I.M. Koropatnik, V.O. Kushnir, O.O. Olifirov, S.V. Pietkov, I.P. Ruschenko, S.M. Salkutsan, O.F. Salnikova, V.M. Tarasov, V.M. Telelym, I.M. Shopina et al.

The main regulatory legal acts are determined, being regulating the activity of the Civil and Military Cooperation Department in Ukraine.

It is determined that after the introduction of the administrative - legal regime of civil and military cooperation in Ukraine in the liberated territories of Ukraine, the confidence of the local residents in the activities of the Armed Forces of Ukraine in the areas of deployment of the force grouping military bases and units has increased. The assistance is provided to the civilian population of the liberated territories, as well as interoperability with other military formations and law enforcement agencies, local authorities, Mass Media, various humanitarian organizations and the private sector in the areas of operation of the joint forces.

It is stated that the process of the administrative and legal regime implementation of the civil-military cooperation is still insufficiently covered by domestic and foreign scientists. We can assume that the main reason for this phenomenon is that the emergence, formation and improvement of the cooperation system between the civilian population and the military organization, starting from the period of existence of the UNR and ZUNR in the history of Ukraine and ending with the present, is characterized by chronic political instability and constant reform of this sphere, especially in modern conditions.

Key words: operation of joint forces, civil and military cooperation, legal regime, Armed Forces of Ukraine, occupation. 